\title{
Effect of plant growth regulators on in vitro regeneration of Lavandula dentata $\mathrm{L}$. shoot tips
}

\author{
Marília Pereira Machado ${ }^{1 *}$, André Luís Lopes da Silva ${ }^{2}$, Luiz Antonio Biasi ${ }^{1}$ \\ ${ }^{1}$ Laboratório de Micropropagação de Plantas, Departamento de Fitotecnia e Fitossanitarismo da Universidade \\ Federal do Paraná (UFPR), Curitiba, PR - Brasil. ${ }^{2}$ Departamento de Engenharia de Bioprocessos e \\ Biotecnologia; UFPR; 81531-970; Curitiba - PR - Brasil.
}

\begin{abstract}
Tissue culture has been used for diverse purposes, being the regeneration of explants, during in vitro establishment, a decisive stage to development of this technique. One of the difficulties encountered in the initial stage, besides contaminations by microorganisms, is the regeneration of the excised explants, which normally requires exogenous source of plant growth regulators. The aim of this research was to evaluate the effect of plant growth regulators on the regeneration of Lavandula dentata shoot tips. Shoot tips were excised and placed on LS culture medium containing $20 \mathrm{~g} \mathrm{~L}^{-1}$ sucrose, $2.5 \mu \mathrm{M}$ indole-3-butyric acid (IBA) and $6 \mathrm{~g} \mathrm{~L}^{-1}$ agar. Different 6-benzylaminopurine $(B A P)$ concentrations with or without $0.3 \mu \mathrm{M}$ gibberellic acid $\left(G A_{3}\right)$ were tested. The experimental design used was random blocks with four replicates of 10 explants per plot. The largest height of shoots was $2.7 \mathrm{~cm}$ obtained on medium containing $0.5 \mu M B A P+2.5 \mu M I B A+0.3 \mu M G A_{3}$. The highest number of leaves per shoot ( \pm 8$)$ was recorded on medium containing $1.0 \mu M B A P+2.5 \mu M I B A$ and higher percentage of regenerated explants (90\%) on medium containing $10.0 \mu M B A P+2.5 \mu M I B A+0.3 \mu M G A_{3}$. Plant growth regulators combinations promote initial development of the shoot tips, and the presence of $G A_{3}$ favor the shoot elongation.
\end{abstract}

Key words: Micropropagation, in vitro establishment, explants, aromatic plants

\section{INTRODUCTION}

The genus Lavandula belongs to the family Lamiaceae and it possesses about 30 species. Lavandula dentata $\mathrm{L}$. stands out as an important medicinal and aromatic plant for producing essential oil with high content of 1,8-cineol, fenchol, borneol and camphor (Sudriá et al., 1999). Besides be used as source of essential oil, it is also used as ornamental and melliferous plant.

Tissue culture constitutes a way to maintain available competent explants and free from contamination for use in in vitro propagation and genetic transformation, besides being highly convenient for conservation of in vitro germplasm and cryopreservation. The tissue culture is also a powerful tool that can accelerate the genetic breeding (Alves et al., 2011).

The regeneration percentage of plants from meristems or shoot tips is low for some plant species. Several factors are pointed as possible causes, such as composition of the culture medium and the concentration and combination of plant growth regulators (Pierik, 1990; Grattapaglia and Machado, 1998).
At the in vitro establishment of explants, the addition of plant growth regulators has the main objective of supplying the possible deficiencies of the endogenous contents of hormones in the explants that one finds isolated of the producing areas in the donor plant (Grattapaglia and Machado, 1998). The cytokinins stimulate the cellular division, and in high concentrations they induce the formation of adventitious shoots and they inhibit the formation of roots. The gibberellins induce the in vitro growth of the meristems or buds, moreover, can also, to break the dormancy of isolated embryos or buds and to inhibit the formation of shoots or adventitious roots. The gibberellic acid $\left(\mathrm{GA}_{3}\right)$ is the gibberellin more used (Carvalho, 1999). The aim of this research was to evaluate the effect of plant growth regulators on in vitro regeneration of Lavandula dentata shoot tips.

\section{MATERIAL AND METHODS}

Adult plants of $L$. dentata cultured in vases inside the greenhouse were used for the isolation of the explants. Shoot tips (ca. $5.0 \mathrm{~mm}$ length) were 
isolated of the donor plants in July of 2008. The disinfection of the explants was accomplished by the wash by one hour in tap water (constant flow), treatment with Cercobin ${ }^{\circledR}$ (2\%) for 40 minutes, proceeded by the immersion in ethanol (70\%) for 20 seconds and $\mathrm{NaOCl}(1 \%)$ added with Tween-20 $(0.2 \%)$ for 20 minutes under agitation and four washes in distilled and sterilized water.

After the disinfection, shoot tips were cultured on Petri dishes containing $25 \mathrm{~mL}$ of LS culture medium (Linsmaier and Skoog, 1965), supplemented with $100 \mathrm{mg} \mathrm{L}^{-1}$ myo-inositol, $20 \mathrm{~g}$ $\mathrm{L}^{-1}$ sucrose, $2.5 \mu \mathrm{M}$ IBA, $6 \mathrm{~g} \mathrm{~L}^{-1}$ agar $\left(\right.$ Vetec $\left.^{\circledR}\right)$ and the $\mathrm{pH}$ was adjusted to 5.8. The treatments were: control (absence of plant growth regulators); 0.5 $\mu \mathrm{M}$ BAP; $0.5 \mu \mathrm{M}$ BAP $+0.3 \mu \mathrm{M} \mathrm{GA}_{3} ; 1.0 \mu \mathrm{M}$ $\mathrm{BAP} ; 1.0 \mu \mathrm{M} \mathrm{BAP}+0.3 \mu \mathrm{M} \mathrm{GA}_{3} ; 2.0 \mu \mathrm{M} \mathrm{BAP}$; $2.0 \mu \mathrm{M}$ BAP $+0.3 \mu \mathrm{M} \mathrm{GA}_{3} ; 5.0 \mu \mathrm{M}$ BAP; $5.0 \mu \mathrm{M}$ $\mathrm{BAP}+0.3 \mu \mathrm{M} \mathrm{GA}_{3} ; 10.0 \mu \mathrm{M}$ BAP; $10.0 \mu \mathrm{M}$ BAP $+0.3 \mu \mathrm{M} \mathrm{GA}_{3}$. The culture media were sterilized at $121{ }^{\circ} \mathrm{C}$, during 20 minutes and $1.5 \mathrm{~atm}$. The $\mathrm{GA}_{3}$ was filtered and added to the culture medium after autoclaving.

The height of explants $(\mathrm{cm})$, leaf number and percentage of regenerated explants were evaluated after 30 days of in vitro culture. The experimental design was random blocks, with four replicates of 10 explants per plot. The data were submitted to analysis of variance (ANOVA) and the means compared by Duncan's test at 5\%. Variables from percentage were transformed to $\arcsin \sqrt{ }(\mathrm{x} / 100)$. All statistical analyses were done following the procedures of the software ASSISTAT version 7.5 beta.

\section{RESULTS AND DISCUSSIOM}

The in vitro regeneration of $L$. dentata shoot tips was significantly influenced by the plant growth regulators tested. The shoot height observed in culture medium containing $0.5 \mu \mathrm{M}$ BAP $+2.5 \mu \mathrm{M}$ $\mathrm{IBA}+0.3 \mu \mathrm{M} \mathrm{GA} \mathrm{GA}_{3}$ was superior $(2.7 \mathrm{~cm})$ when compared to other treatments. The supplementation with $\mathrm{GA}_{3}$ promoted an increase in shoot height, whereas in treatments with lack of $\mathrm{GA}_{3}$ was not observed significant shoot elongation (Table 1). The effect more well-known of gibberellins is the elongation of aerial part (Grattapaglia and Machado, 1998). In studies with L. dentata (Echeverrigaray et al., 2005), L. vera (Quazi, 1980) and L. latifolia (Calvo and Segura, 1989), the increase in the shoot height only occurred with combinations of IBA and BAP added in culture medium. The nutritional exigencies requested for the growth of a tissue in in vitro conditions can vary of species for species, of genotype for genotype and even inside of the own plant (Nagao et al., 1994).

In the treatment $1.0 \mu \mathrm{M}$ BAP $+2.5 \mu \mathrm{M}$ IBA was obtained the largest number of leaves per shoot, ca. 8 leaves per shoot. The smallest number of leaves was ca. 5 leaves per shoot found in the treatments $0.5 \mu \mathrm{M} \mathrm{BAP}+2.5 \mu \mathrm{M} \mathrm{IBA}+0.3 \mu \mathrm{M}$ $\mathrm{GA}_{3}$ and in $2.5 \mu \mathrm{M} \mathrm{BAP}+2.5 \mu \mathrm{M} \mathrm{IBA}+0.3 \mu \mathrm{M}$ $\mathrm{GA}_{3}$ (Table 1).

The largest percentage of regenerated explants was promoted by the treatment $10.0 \mu \mathrm{M} \mathrm{BAP}+2.5$ $\mu \mathrm{M} \mathrm{IBA}+0.3 \mu \mathrm{M} \mathrm{GA}_{3}$, in which $90 \%$ of the explants formed new shoots (Table 1). The supplementation with BAP or kinetin in the culture medium promoted from 50 to $68 \%$ more axillary buds of $L$. dentata, that in the cytokinins absence (Jordan et al., 1998). The results found in this research demonstrate that the capacity of regeneration of $L$. dentata shoot tips in the absence of growth regulator in the culture medium is of approximately $35 \%$ (Table 1 ). The balance of the plant growth regulators, added in the culture medium, associated with the hormones produced by the own plant, presents great importance in the regeneration of tissues in vitro, being one of the main responsible factors for the division, differentiation and expansion of the cells (Oliveira et al., 1995).

The fact of the explants have been isolated of the donor plants in the winter (July), can have been influencing in the low regeneration percentage in the absence of $\mathrm{GA}_{3}(30-45 \%)$, considering that the explants retreat should be made of preference from new shoots that are formed during the active phase of growth of the plant, during the hottest months of the year, but not always the explants removed in the growth period is the most suitable (Grattapaglia and Machado, 1998). Therefore, studies about the period of isolation of the explants of $L$. dentata should be accomplished, to suppress the use of plant growth regulators in the in vitro establishment for reduction of costs.

\section{CONCLUSIONS}

The combinations of plant growth regulators promote the initial development of shoot tips and the presence of $\mathrm{GA}_{3}$ allows shoots more elongated. The in vitro regeneration of shoot tips of $L$. dentata is higher when cultured with 
supplementation of $10.0 \mu \mathrm{M} \mathrm{BAP}+2.5 \mu \mathrm{M} \mathrm{IBA}+$ $0.3 \mu \mathrm{M} \mathrm{GA}_{3}$.

Table 1- Effect of plant growth regulators in the height, leaf number and percentage of regenerated explants after 30 days from in vitro establishment of Lavandula dentata L. shoot tips.

\begin{tabular}{cccc}
\hline $\begin{array}{c}\text { Plant growth regulators } \\
(\boldsymbol{\mu M})\end{array}$ & $\begin{array}{c}\text { Height } \\
(\mathbf{c m})^{\mathbf{1}}\end{array}$ & $\begin{array}{c}\text { Leaf } \\
\text { number }^{\mathbf{1}}\end{array}$ & $\begin{array}{c}\text { Regenerated explants } \\
(\mathbf{\%})^{\mathbf{1}}\end{array}$ \\
\hline Control & $0.9 \mathrm{~d}$ & $6.1 \mathrm{cde}$ & $35.5 \mathrm{~d}$ \\
$0.5 \mathrm{BAP}+2.5 \mathrm{IBA}$ & $0.6 \mathrm{e}$ & $5.8 \mathrm{de}$ & $35.0 \mathrm{~d}$ \\
$0.5 \mathrm{BAP}+2.5 \mathrm{IBA}+0.3 \mathrm{GA}_{3}$ & $2.7 \mathrm{a}$ & $5.3 \mathrm{e}$ & $73.3 \mathrm{~b}$ \\
$1.0 \mathrm{BAP}+2.5 \mathrm{IBA}$ & $1.2 \mathrm{c}$ & $7.8 \mathrm{a}$ & $23.3 \mathrm{e}$ \\
$1.0 \mathrm{BAP}+2.5 \mathrm{IBA}+0.3 \mathrm{GA}_{3}$ & $2.4 \mathrm{~b}$ & $6.2 \mathrm{bcde}$ & $66.5 \mathrm{~b}$ \\
2.0 BAP + 2.5 IBA & $0.8 \mathrm{de}$ & $7.1 \mathrm{abc}$ & $30.0 \mathrm{de}$ \\
2.0 BAP + 2.5 IBA + 0.3 GA 3 & $2.3 \mathrm{~b}$ & $5.5 \mathrm{e}$ & $73.3 \mathrm{~b}$ \\
5.0 BAP + 2.5 IBA & $0.8 \mathrm{de}$ & $5.8 \mathrm{cde}$ & $45.0 \mathrm{c}$ \\
$5.0 \mathrm{BAP}+2.5 \mathrm{IBA}+0.3 \mathrm{GA}_{3}$ & $2.3 \mathrm{~b}$ & $7.0 \mathrm{abcd}$ & $65.0 \mathrm{~b}$ \\
10.0 BAP + 2.5 IBA & $1.3 \mathrm{c}$ & $7.5 \mathrm{ab}$ & $33.3 \mathrm{~d}$ \\
$10.0 \mathrm{BAP}+2.5 \mathrm{IBA}+0.3 \mathrm{GA}_{3}$ & $2.3 \mathrm{~b}$ & $5.6 \mathrm{de}$ & $90 \mathrm{a}$ \\
\hline CV $(\%)$ & 8.35 & 13.90 & 7.31 \\
\hline
\end{tabular}

1 Means followed by the same letter in columns are not significant by Duncan's test at $5 \%$.

\section{RESUMO}

A cultura de tecidos tem sido utilizada com diversas finalidades, sendo a regeneração dos explantes, na fase de estabelecimento da cultura, uma etapa determinante para a realização da técnica. Uma das dificuldades encontradas na fase inicial, além da contaminação por microorganismos, é a capacidade de regeneração dos explantes isolados, que normalmente necessitam de uma fonte exógena de regulador de crescimento para seu desenvolvimento. O objetivo desse trabalho foi avaliar o efeito de reguladores de crescimento na regeneração de ápices caulinares de Lavandula dentata. Ápices caulinares foram isolados em meio de cultura LS, acrescido de $20 \mathrm{~g} \mathrm{~L}^{-1}$ de sacarose, 2,5 $\mu \mathrm{M}$ ácido indolbutírico (IBA) e $6 \mathrm{~g} \mathrm{~L}^{-1}$ de agar. Foram testadas diferentes concentrações de 6-benzilaminopurina (BAP) combinadas ou não com $0,3 \mu \mathrm{M}$ de ácido giberélico $\left(\mathrm{GA}_{3}\right)$. O delineamento experimental foi em blocos casualizados, com quatro repetições de 10 explantes por parcela. A maior altura das brotações foi $2,7 \mathrm{~cm}$ obtida com $0,5 \mu \mathrm{M}$ de BAP $+2,5 \mu \mathrm{M}$ de IBA $+0,3 \mu \mathrm{M}$ de $\mathrm{GA}_{3}$. $\mathrm{O}$ maior número de folhas por brotação foi obtido com $1,0 \mu \mathrm{M}$ de BAP $+2,5 \mu \mathrm{M}$ de IBA, sendo ca. 8 folhas por brotação. A maior porcentagem de explantes regenerados foi obtida com o tratamento $10,0 \mu \mathrm{M}$ de $\mathrm{BAP}+2,5 \mu \mathrm{M}$ de IBA $+0,3 \mu \mathrm{M}$ de $\mathrm{GA}_{3}$, no qual $90 \%$ dos explantes formaram novas brotações. Concluiu-se que a combinação dos reguladores de crescimento testados promoveu o desenvolvimento inicial dos ápices caulinares, e na presença de $\mathrm{GA}_{3}$ foram obtidas brotações mais longas.

Palavras-chave: Micropropagação, estabelecimento in vitro, explante, plantas aromáticas

\section{REFERENCES}

Alves, S. A. O.; Lemos, O. F. de; Santos Filho, B. G.; Silva, A. L. L. da. (2011), In vitro embryo rescue of interspecific hybrids of oil palm (Elaeis oleifera $\mathrm{x}$ Elaeis guineensis). Journal of Biotechnology and Biodiversity, 2, 1-6.

Calvo, M. C.; Segura, J. (1989), In vitro propagation of lavender. HortScience, 24, 375376.

Carvalho, J. M. F. C. de. (1999), Técnicas de micropropagação. Campina Grande: EMBRAPA Algadão, 39p. (Documentos 64).

Echeverrigaray, S.; Basso, R.; Andrade, L.B. (2005), Micropropagation of Lavandula dentata from axillary buds of field-grown adult plants. Biologia Plantarum, 49, 439-442.

Grattapaglia, D.; Machado, M. A. (1998), Micropropagação. In: Torres, A. C.; Caldas, L. S.; Buso, J. A. Cultura de tecidos e transformação genética de plantas. v. 1, Brasília: EMBRAPA, $508 \mathrm{p}$.

Jordan, A. M.; Calvo, M. C.; Segura, J. (1998), Micropropagation of adult Lavandula dentata plants. Journal of Horticultural Science \& Biotechnology, 73, 93-96. 
Linsmaier, E.M.; Skoog, F. (1965), Organic growth factors requirements of tobacco tissue cultures. Physiologia Plantarum, 18, 100-127.

Nagao, E. O.; Pasqual, M.; Ramos, J. D. (1994), Efeitos da sacarose e do nitrogênio inorgânico sobre a multiplicação in vitro de brotações de porta-enxerto de citros. Bragantia, 53, 25-31.

Oliveira, P. P.; Pasqual, M. E.; Paiva, R. (1995), Efeito de diferentes reguladores de crescimento sobre a proliferação in vitro de brotos de Crisântemo (Dendranthema grandiflora tzevelev). Ciência e Prática, 19, 390-396.

Pierik, R. L. M. (1990), Produccion de plantas libres de enfermedades In: Pierik, R.L.M. (Ed.) Cultivo in vitro de las plantas superiores. Madrid: Ediciones Mundi-Pronsa, 1990. p.169-180.
Sudriá, C.; Piñol, M. T.; Palazon, J.; Cusido, R. M.; Vila, R. ; Morales, C.; Bonfill, M.; Canigueral, S. (1999), Influence of plant growth regulators on the growth and essential oil content of cultured Lavandula dentata plants. Plant Cell, Tissue and Organ Culture, 58, 177-184.

Quazi, M. H. (1980), In vitro propagation of Lavandula spp. Annals of Botany, 45, 361-362. 